\title{
PANCASILA SEBAGAI IDEOLOGI NEGARA DAN HAK ASASI MANUSIA DALAM MENJAGA KEUTUHAN NEGARA KESATUAN REPUBLIK INDONESIA
}

Oleh :

Dra. Luh Suryatni, MSi ${ }^{1}$

\begin{abstract}
ABSTRACK :
Ideology in our life as a State can be interpreted as the majority consensus of citizens about the basic values that they want to realize by establishing a State. In this case, it is often also referred to as philosophische grondslag or weltanschauung, which is the deepest thought and desire of its citizens to establish a state. Ideology and personality of the Indonesia as a crystallization of the sacred values of Indonesia as a nation, puts human in the lofty dignity as a sentient that believe God Almighty with the awareness of carrying out his nature as being personal and social beings. As enshrined in the preamble to the Constitution of 1945, where the Unitary State of the Republic of Indonesia (NKRI) respects any attempt of a nation for outlining and regulating human rights in accordance with the system of values and ideology of each. In this case, Indonesia as a nation will uphold and enforce human rights that corresponding to the Pancasila as the State ideology as to remain firmly hold as Unitary State of the Republic of Indonesia
\end{abstract}

Keywords : Ideology, Pancasila, Human Rights, State

\footnotetext{
${ }^{1}$ Dosen Tetap Fakultas Hukum Universitas Suryadarama dan aktif sebagai anggota Majelis Pengawas Daerah Notaris Wilayah Jakarta Timur
} 


\section{PENDAHULUAN}

Setiap bangsa yang ingin berdiri kokoh dan mengetahui dengan jelas ke arah mana tujuan yang ingin dicapai memerlukan ideologi. Dimana suatu bangsa akan memandang persoalan-persoalan yang dihadapi dan menentukan cara bagaimana memecahkan persoalan tersebut. Sehingga konsep dasarnya ialah pikiran-pikiran yang didalamnya terkandung gagasan mengenai wujud kehidupan yang dianggap baik yang dicita-citakan suatu bangsa, dan sudah diyakini kebenarannya jika dapat menimbulkan tekad untuk mewujudkannya. Ideologi dalam kehidupan kenegaraan dapat diartikan sebagai suatu konsensus mayoritas warga negara tentang nilai-nilai dasar yang ingin diwujudkan dengan mendirikan negara, dalam hal ini sering juga disebut philosofische grondslg atau weltanschuung yang merupakan pikiran-pikiran terdalam, hasrat terdalam warga negaranya, untuk diatasnya didirikan suatu negara.

Dalam hal ini, Pancasila dipergunakan sebagai petunjuk hidup sehari-hari, yang diamalkan dalam kehidupan sehari-hari dan sebagai pedoman dalam semua kegiatan/aktivitas hidup di segala bidang, tidak boleh bertentangan dengan norma-norma agama, hukum, kesusilaan, dan norma sopan santun. Jadi, Pancasila sebagai ideologi negara menjadi sarana ampuh dalam mempersatukan bangsa Indonesia dan dapat memberi petunjuk dalam mencapai kesejahteraan dan kebahagiaan lahir batin bagi masyarakat Indonesia yang beraneka ragam.
Tidak dapat dipungkiri bahwa kelahiran Pancasila sebagai ideologi negara, meskipun berjalan alot, tetapi dalam batas-batas tertentu dapat dikatakan berlangsung secara signifikan. Berbeda dengan proses kelahirannya, upaya "membumikan" Pancasila di tengah bangsa Indonesia ternyata banyak menghadapi tantangan dan cobaan. Tantangan terhadap Pancasila sudah mulai tampak sejak masa-masa awal bangsa Indonesia menyatakan kemerdekaannya. Tantangan terhadap eksistensi Pancasila tidak hanya bersifat internal tapi juga bersifat eksternal.

Berpijak pada realitas adanya berbagai tantangan dan ancaman terhadap Pancasila sebagai ideologi negara sejak masa-masa awal kelahirannya, bisa dipastikan bahwa tantangan dan ancaman terhadap Pancasila akan terus berlangsung. Maka dari itu, mau tidak mau, apabila Pancasila ingin tetap eksis di bumi Nusantara ini perlu selalu dipersiapkan jawaban (respons) yang tepat atas berbagai tantangan yang tengah dan akan terjadi.

\section{PERMASALAHAN}

Berdasarkan uraian tersebut diatas, yang menjadi masalah dalam tulisan ini adalah:

" Apakah Pancasila Sebagai Ideologi Negara dan Hak Asasi Manusia Dapat Menjaga Keutuhan Negara Kesatuan Republik Indonesia? “

\section{PEMBAHASAN}

Filsafat merupakan suatu ajaran nilai atau kebenaran yang dijadikan 
keyakinan atau ideologi suatu bangsa. Bagi suatu bangsa, kebenaran ini dijadikan dasar negara atau ideologi negara. Ideologi berasal dari kata ideo yang berarti cita-cita dan logy yang berarti pengetahuan, ilmu dan paham. Menurut W. White, definisi dari ideologi adalah: the sum of political ideas or doctrines of a distinguishable class or group of people; artinya: ideologi adalah soal cita-cita politik atau doktrin atau ajaran suatu lapisan masyarakat atau sekelompok manusia yang dapat dibeda-bedakan.

Sedangkan menurut pendapat Harol. H. Titus, yang dikutip dari C.ST. Kansil, definisi dari itu adalah: a term used for any group of ideas concerning various political and economic issues and social philosphies often applied to a systematic scheme of ideas held by groups or classes; artinya: suatu istilah yang dipergunakan untuk sekelompok cita-cita mengenai berbagai macam masalah politik dan ekonomi filsafat sosial yang sering dilaksanakan bagi suatu rencana yang sistematis tentang cita-cita yang dijalankan oleh kelompok atau lapisan masyarakat.

Jadi, bila definisi-definisi ini diterapkan pada Pancasila, maka dapat disimpulkan bahwa Pancasila itu adalah hasil usaha pemikiran manusia Indonesia untuk mencari kebenaran, kemudian sampai mendekati atau menganggap sebagai suatu kesanggupan yang digenggamnya seirama dengan ruang dan waktu. Hasil pemikiran manusia Indonesia yang secara sungguhsungguh dan sistematis, kemudian dituangkan dalam suatu rumusan rangkaian kalimat yang mengandung satu pemikiran yang bermakna bulat dan utuh untuk dijadikan dasar, asas, dan pedoman atau norma hidup dan kehidupan bersama dalam rangka perumusan suatu negara Indonesia merdeka, yang diberi nama Pancasila. Pancasila yang dikemukakan dalam Sidang I BPUPKI pada 1 Juni 1945 adalah dimaksudkan untuk menjadi dasar dari negara Indonesia Merdeka.

Adapun dasar itu harus berupa suatu falsafah yang me $\neg$ nyimpulkan kehidupan dan cita-cita bangsa dan negara Indonesia yang merdeka. Di atas dasar itu akan didirikan gedung Republik Indonesia sebagai perwujudan kemerdekaan politik yang menuju kepada kemerdekaan ekonomi, sosial dan kebudayaan. Landasan atau dasar itu kuat dan kokoh agar gedung yang berdiri di atasnya akan tetap tegak sentosa untuk selama-lamanya. Landasan itu pula tahan uji terhadap seranganserangan baik dari dalam maupun dari luar. Sidang BPUPKI telah menerima secara bulat Pancasila itu sebagai dasar negara Indonesia. Dalam keputusan sidang PPKI kemudian pada tanggal 18 Agustus tahun 1945 pancasila tercantum secara resmi dalam pembukaan UUD RI 1945. Undang-Undang Dasar yang menjadi sumber ketata $\neg$ negaraan harus mengandung unsur-unsur pokok yang kuat dan menjadi landasan hidup bagi seluruh bangsa dan negara, agar peraturan dasar itu tahan uji sepanjang masa.

Peraturan-peraturan selanjutnya yang disusun untuk mengatasi dan menyalurkan persoalan-persoalan yang timbul berhubung dengan penyelenggaraan dan perkembangan negara harus didasarkan atas dan 
berpedoman pada Undang-Undang Dasar. Peraturan-peraturan yang bersumber pada UUD itu disebut peraturan-peraturan organik, yang menjadi pelaksana dari UUD. Oleh karena Pancasila tercantum dalam UUD 1945 dan bahkan men $\neg$ jiwai seluruh isi peraturan dasar tersebut yang berfungsi sebagai dasar negara sebagaimana tercantum jelas dalam alinea IV Pembukaan UUD 1945, maka semua peraturan perundangundangan dengan Republik Indonesia (ketetapan MPR, Undang-Undang, Peraturan Pemerintah pangganti Undang - Undang, Peraturan Pemerintah, Keputusan Presiden dan peraturan - peraturan pelaksanaan Iainnya) yang dikeluarkan oleh negara dan pemerintah Republik Indonesia harus pula sejiwa dengan Pancasila (dijiwai oleh dasar negara Pancasila).

Isi dan tujuan dari peraturan perาundang-undangan Republik Indonesia tidak boleh menyimpang dari jiwa Pancasila. Keputusan Sidang PPKI pada tanggal 18 Agustus 1945 menetapkan Undang-Undang Dasar bagi negara Republik Indonesia yang telah diprok $\neg$ lamasikan pada tanggal 17 Agustus 1945. Undang-Undang Dasar tersebut ialah UUD 1945. Dalam Pembukaan UUD 1945 kita temukan dasar negara "Pancasila".

Pancasila sebagai dasar negara, maka mengamalkan dan mengamankan Pancasila sebagai dasar negara mempunyai sifat imperatif dan memaksa, artinya, setiap warga negara Indonesia harus tunduk dan taat kepadanya. Siapa saja yang melanggar Pancasila sebagai dasar negara, harus ditindak menurut hukum, yakni hukum yang berlaku di negara Indonesia. Dengan kata lain, pengamalan Pancasila sebagai dasar negara disertai sanksi-sanksi hukum. Sedangkan pengamalan Pancasila sebagai weltanschuung, yaitu pelaksanaan Pancasila dalam hidup sehari-hari tidak disertai sanksi-sanksi hukum, tetapi memiliki sifat yang mengikat, artinya setiap manusia Indonesia terikat dengan cita-cita yang terkandung di dalamnya untuk mewujudkan dalam hidup dan kehidupannya, sepanjang tidak melanggar peraturan perundangundangan yang berlaku.

Pancasila sebagai filsafat bangsa dan ideologi negara dihubungkan dengan fungsinya sebagai dasar negara, yang merupakan landasan idiil bangsa Indonesia dan negara Republik Indonesia dapat disebut pula sebagai Ideologi Nasional atau lebih tepat lagi ideologi negara. Artinya Pancasila merupakan satu ideologi yang dianut oleh negara atau pemerintah dan rakyat Indonesia secara keseluruhan, bukan milik atau dapat dimonopoli oleh seseorang, ataupun sesuatu golongan masyarakat tertentu. Sebagai dasar filsafat atau dasar kerohanian negara, yang merupakan cita-cita bangsa, Pancasila harus dilaksanakan atau diamalkan.

Pancasila di era globalisasi merupakan realitas kontemporer memperlihatkan bahwa tantangan terhadap ideologi Pancasila, baik kini maupun nanti, beberapa diantaranya telah tampak di permukaan. Tantangan dari dalam diantaranya berupa berbagai gerakan separatis yang hendak memisahkan diri dari Negara Kesatuan Republik Indonesia (NKRI). Apa yang pernah terjadi di Aceh, Maluku, dan Papua, 
merupakan sebagian contoh di dalamnya. Penanganan yang tidak tepat dan tegas dalam menghadapi gerakan-gerakan tersebut akan menjadi ancaman serius bagi tetap eksisnya Pancasila di bumi Indonesia. Bahkan, bisa jadi akan mengakibatkan Indonesia tinggal sebuah nama sebagaimana halnya Yugoslavia dan Uni Soviet.

Tidak kalah seriusnya dengan tantangan dari dalam, Pancasila juga kini tengah dihadapkan dengan tantangan eksternal berskala besar berupa mondialisasi atau globalisasi. Globalisasi yang berbasiskan pada perkembangan teknologi informasi, komunikasi dan transportasi, secara drastis telah mentransendensi batasbatas etnis bahkan bangsa. Jadi bangsa Indonesia kini, tanpa bisa dihindari dan menghindari menjadi bagian dari arus besar berbagai perubahan yang terjadi di dunia. Sekecil apapun perubahan yang terjadi di belahan dunia lain akan langsung diketahui atau bahkan dirasakan akibatnya oleh Indonesia. Sebaliknya, sekecil apapun peristiwa yang terjadi di Indonesia secara cepat akan menjadi bagian dari konsumsi informasi masyarakat dunia. Pengaruh dari globalisasi ini dengan demikian begitu cepat dan mendalam.

Menjadi sebuah pertanyaan besar bagi bangsa Indonesia, sanggupkah Pancasila menjawab berbagai tantangan tersebut? Akankah Pancasila tetap eksis sebagai ideologi negara yang mencerminkan HAM? Jawabannya tentu akan berpulang kembali pada bangsa Indonesia sendiri sebagai pemilik Pancasila. Namun demikian, untuk mencari jawaban atas berbagai tantangan tersebut, maka jawaban adalah bahwa Pancasila akan sanggup menghadapi berbagai tantangan tersebut asalkan Pancasila benar-benar mampu diaplikasikan sebagai weltanschauung bangsa Indonesia, mengingat Pancasila akan dapat mempengaruhi kehidupan bangsa Indonesia apabila Pancasila mendapatkan ruh dari jiwa bangsa Indonesia.

Implikasi dari dijadikannya Pancasila sebagai ideologi maka bangsa yang besar ini harus mempunyai rasa kepemilikan dan rasa bangga atas Pancasila. Untuk menumbuhkembangkan kedua rasa tersebut maka melihat realitas yang tengah berkembang saat ini setidaknya dua hal mendasar perlu dilakukan. Pertama, penanaman kembali kesadaran bangsa tentang eksistensi Pancasila sebagai ideologi negara. Penanaman kesadaran tentang keberadaan Pancasila sebagai ideologi bangsa mengandung pemahaman tentang adanya suatu proses pembangungan kembali kesadaran akan Pancasila sebagai identitas nasional.

Upaya ini memiliki makna strategis manakala realitas menunjukkan bahwa dalam batas-batas tertentu telah terjadi proses pemudaran kesadaran tentang keberadaan Pancasila sebagai ideologi bangsa. Salah satu langkah terbaik untuk mendekatkan kembali atau membumikan kembali Pancasila ketengah rakyat Indonesia tidak lain melalui pembangunan kesadaran historis (baik melalui pendidikan formal maupun nonformal). Tegasnya Pancasila didekatkan kembali dengan 
cara menguraikannya sebagai bagian yang tak terpisahkan dari perjuangan rakyat Indonesia, termasuk menjelaskannya bahwa secara substansial Pancasila adalah jawaban yang tepat dan strategis atas keberagaman Indonesia, baik pada masa lalu, masa kini, maupun masa yang akan mendatang. Kedua adalah perlu adanya kekonsistenan dari seluruh elemen bangsa, khusunya para pemimpin negeri ini untuk menjadikan Pancasila sebagai pedoman dalam berpikir,bersikap, dan bertindak. Jangan sampai Pancasila ini sekadar wacana di atas mulut yang disampaikan secara berbusa-busa hingga menjadi basi sementara di lapangan penuh dengan perilaku munafik. Dengan demikian, penghayatan dan pengamalan sila-sila Pancasila dalam kehidupan seharihari merupakan suatu conditio sine qua non bagi tetap tegaknya Pancasila sebagai ideologi negara.

Salah satu tantangan terbesar yang perlu segera dijawab bangsa Indonesia khususnya, oleh para pemegang kekuasaan adalah menjawab tantangan atas lemahnya kesejahteraan rakyat dan penegakan keadilan. Ketimpangan kesejahteraan antara kota dan desa, terlebih lagi yang terjadi di Jawa dan luar Jawa merupakan salah satu permasalahan besar yang harus segera dijawab oleh bangsa ini. Perlu diingat bahwa dewasa ini masih ada bagian dari bangsa ini yang secara mengenaskan masih hidup bagaikan di masa prasejarah. Masalah penegakan keadilan juga menjadi masalah yang perlu mendapat perhatian serius para pengambil kebijakan. Keadilan sosial yang telah lama digariskan para pendiri negara ini sering menjadi kontraproduktif manakala hendak ditegakkan di kalangan para penguasa dan pemilik uang. Jadilah hingga sekarang ini pisau keadilan yang dimiliki bangsa ini masih merupakan pisau keadilan bermata ganda, tajam manakala diarahkan kepada rakyat kebanyakan, dan tumpul atau bahkan kehilangan ketajamannya sama sekali manakala dihadapkan dengan para pemegang kekuasaan atau pemilik sumber-sumber ekonomi.

Bila dua hal itu saja mampu dikedepankan, bisa jadi bangsa Indonesia tidak akan mudah tergoyahkan oleh berbagai tantangan dan ancaman yang ada, baik dari dalam maupun dari luar. Ancaman dari dalam bisa jadi akan pupus dengan sendirinya apabla kesejahteraan rakyat terkondisikan pada keadaan yang baik dan keadilan dapat ditegakkan dengan seadiladilnya. Ancaman dari luar, termasuk arus besar globalisasi sekalipun tidak akan menggeruskan Pancasila sebagai sebuah ideologi tetapi justru akan menjadikan Pancasila sebagai kekuatan yang mampu mewarnai arus besar ini. Terlebih lagi, karena globalisasi bagi bangsa ini bukanlah barang baru.

Tidak dapat dipungkiri bahwa sebuah negara bangsa membutuhkan weltanschauung atau landasan filosofis. Atas dasar landasan filosofis inilah, maka dapat disusun visi, misi dan tujuan negara. Tanpa itu, negara bergerak seperti layangan putus, tanpa pedoman. Itu saja yang membuat Pancasila bertahan selama ini. Oleh karena itu, pemerintah bahkan tidak pernah sekalipun berani menyinggung 
atau mempertanyakan relevansi dari Pancasila. Karena sudah terhujam dengan sangat dalam di hati seluruh rakyat Indonesia bahwa "Pancasilalah" yang mempersatukan bangsa ini. Apa benar? Secara simbolis memang Pancasila adalah alat pemersatu bangsa yang merupakan jiwa, kepribadian dan ideologi bangsa Indonesia, dan berdasarkan sejarah Pancasila juga merupakan sumber kekuatan bagi perjuangan karena menjadikan bangsa Indonesia bersatu. Benarkah begitu? Setidaknya itulah yang selalu dipropagandakan pemerintah. Untuk mengusut sejak kapan 'Pancasila sebagai Ideologi' negara ini, cukup sulit karena sejarah Indonesia tidak murni hitam-putih tetapi abu-abu. Tidak pasti mana kejadian yang terjadi, mana yang hanya rekayasa semata. Kejernihan mata reformasi bahkan tidak sanggup menembus kabut kelamnya masa lalu bangsa ini.

Tetapi bukan hal ini yang ingin dibahas saat ini. Seperti yang telah disebutkan di atas bahwa secara simbolis Pancasila benar-benar secara kuat mempersatukan bangsa ini, dan apabila kita mempertanyakan keabsahan Pancasila, yang terjadi adalah disintegrasi lagi. Oleh karena itu diperlukan langkah strategis dalam pemahaman Ideologi negara dan Hak Asasi Manusia yang dapat mempertahankan kesatuan NKRI. Yang sampai saat ini hal tersebut belum dapat terwujud karena kurangnya implementasi nilai Pancasila dalam kehidupan bermasyarakat, berbangsa dan bernegara. Paham kekeluargaan dan kebersamaan berdasarkan Panca $\neg$ sila sebagai Dasar Negara dan Pandangan hidup bangsa terasa hanya sebagai slogan dan ungkapan umum para tokoh / pemuka agama/ pejabat / pakar yang pada gilirannya terimpikasi dalam sikap mental sebagian masyarakat (pelanggaran HAM, kerusuhan, penjarahan, pemberontakan dan pelecehan aparatur serta pelanggaran Hukum). Disamping itu hal ini telah mendorong masyarakat untuk main hakim sendiri. Perlindungan Hukum kurang dirasakan dan ketidakadilan semakin menonjol dalam kehidupan masyarakat umum dan berkembangnya opini tidak mempercayai pemerintah, disertai belum berhasilnya pemerintah mengungkap berbagal kasus yang terjadi, telah semakin merangsang sikap oposisi rakyat terhadap pemerintah.

Apresiasi terhadap suasana kehidupan kenegaraan dan kebang $\neg$ saan yang mengandung potensi disintegrasi seperti disebutkan di atas, menggambarkan telah terancamnya keutuhan bangsa dan negara, apabila tidak segena di $\neg$ benahi secara tepat dan konsepsional. Disadari bahwa keBhinekaan yang tidak lain adalah keanekaragaman dan me $\neg$ ngandung banyak perbedaan dan prinsip sifatnya. Perbedaan suku, agama, adat istiadat, karakter, interest, intelektual, kesejahtenaan, power, sikap mental, demografi, geografis, pengalaman, kebudayaan dan banyak lagi keragaman itu, dapat terkendali hanya dengan adanya kesamaan nilai-nilai filosofis yang menjadi dasar negara dan pandangan hidup bangsa yang Bhineka itu Pancasila yang dirumuskan oleh pendiri negara, telah ditetapkan sebagai nilai-nilai dasar 
yang sangat fundamental bagi kehidupan bernegara dan berbang $\urcorner$ sa itu, harus benar-benar diwujudkan.

Negara persatuan atau negara kekeluargaan yang integralistik dan terbentang dari Sabang sampai Merauke (Papua) harus diterima sebagai suatu kompromi nasional, apabila kita ingin utuh sebagai suatu bangsa. Dengan demikian, Pancasila sebagai Falsafah bangsa, Dasar Negara dan Pandangan Hidup Bangsa, benar-benar menjadi Pemersatu Bangsa yang kaya dengan keragaman sebagai ciri khas dari NKRI. Mengingat masalah besar seperti Integrasi Nasional/Persatuan dan Kesatuan tidak akan terselesaikan dalam beberapa tahun, tetapi mem $\neg$ butuhkan waktu cukup lama dan harus diperjuangkan terusmenerus.

Pembukaan UUD 1945 yang menjadi pokok kaidah fundamental negara sekaligus sebagai sumber hukum yang di dalamnya terkan $\neg$ dung nilai-nilai Pancasila, ternyata selama ini tidak sepenuhnya diᄀterapkan dalam kehidupan hukum Nasional. Hal ini berakibat pada lemahnya materi hukum dan perundangan yang harus dibenahi secara serius, serta aparat hukum yang kurang menjadikan nilainilai Pancasila sebagai acuan untuk menata etika hukum. Giliran berikut adalah lemahnya budaya hukum dalam kehidupan nasional sehingga hukum tidak diwibawakan dalam sistem nilai secara nasional dan berakibat langsung pada lemahnya penegakan hukum. Apabila Law Enforcement meningkat dan kuat, maka hukum dengan sendirinya akan menjadi pengayom masya $\neg$ rakat, yang berarti keadilan dapat diwujudkan dalam segala segi ke $\neg$ hidupan nasional. Apalagi bila budaya hukum masyarakat itu disemangati oleh nilai-nilai luhur Pancasila yang digali dari budaya Indonesia sendiri. Mantapnya kehidupan hukum, akan menjamin tenwujudnya rasa keadilan dalam masyarakat sehingga dapat meredam kecemburuan akibat ketidakadilan, yang pada gilirannya akan menimbulkan kewibawaan dalam manajemen nasional yang bebas dari kelemahan - kelemahan administratif, bebas dari tindakan-tindakan KKN (Korupsi, Kolusi dan Nepotisme) sehingga kepercayaan masyarakat kepada aparatur pemerintah dapat ditingkatkan. Sudah saatnya kepedulian seluruh masyarakat bangsa digalakkan untuk ikut serta membantu dalam mencari jalan keluar dari permasalahan ini secara demokratis.

Sebagaimana juga yang telah dijelaskan oleh Jimly Asshiddiqie dalam seminar memperingati hari kesaktian pancasila pada tanggal 1 Oktober 2011 di kampus Universitas Pancasila, Jakarta menegaskan bahwa Pancasila pada pokoknya tidak dapat dipisahkan dari UUD 1945. UUD 1945 dapat dipandang sebagai jasadnya, sedangkan Pancasila adalah rohnya. Karena itu, UUD 1945 tidak dapat dipahami terpisah atau pun di luar konteks dari rohnya, yaitu Pancasila. Sebaliknya, Pancasila juga tidak dapat dilihat berdiri sendiri melainkan harus dibaca dan dipahami dalam konteks sistem norma konstitusional yang menjadi jasadnya, yaitu norma UUD 1945.

Meski tidak ada penegasan bahwa kelima sila dalam Alinea ke-IV 
Pembukaan UUD 1945 dinamakan Pancasila, tetapi secara implisit, Pasal 36A UUD 1945 telah menyebutkan istilah Pancasila itu dalam rangka penegasan mengenai lambang negara. Pasal 36A itu menentukan, "Lambang Negara ialah Garuda Pancasila dengan semboyan Bhinneka Tunggal Ika". Namun, eksistensi dan penamaan Pancasila atas rumusan lima sila dalam Alinea ke-IV Pembukaan UUD 1945 itu merupakan produk sejarah yang berdasarkan konvensi ketatanegaraan diakui sangat kuat kedudukannya dengan tidak memerlukan penegasan hukum apapun lagi. Apalagi, Pasal II Aturan Tambahan UUD 1945 menegaskan bahwa "Dengan ditetapkannya Undang-Undang Dasar ini, Undang-Undang Dasar Negara Republik Indonesia Tahun 1945 terdiri atas pembukaan dan pasalpasal".

Sebaliknya. dalam ketentuan mengenai perubahan undang-undang dasar pada Pasal 37, ditentukan bahwa yang dapat dijadikan objek perubahan menurut prosedur berdasarkan Pasal 37 UUD 1945 adalah pasal-pasal UUD Negara Republik Indonesia Tahun 1945 saja, dan tidak termasuk pembukaannya. Artinya, eksistensi Pancasila dalam Pembukaan UUD 1945 bersifat final, tidak dapat diubah lagi, dan sebaliknya, kandungan norma dalam UUD 1945 itu sudah tidak dapat lagi dipisah-pisahkan dari nilai-nilai Pancasila yang terdapat dalam Pembukaan UUD 1945 itu. Hal ini dipertegas lagi oleh Presiden Susilo Bambang Yudhoyono dalam pidato kenegaraan pada sidang Paripurna DPR-RI tanggal 15 Agustus 2014 bahwa "Kita harus menjaga ke-
Indonesiaan kita, perjuangan kita di abad ke-21 ini tidak lagi menjaga kemerdekaan namun menjaga keIndonesiaan. Tidak ada gunanya kita semakin makmur dan modern, namun kehilangan yang amat fundamental dan terbaik dari bangsa Indonesia kita, yaitu : Pancasila, ke-Bhinekaan, semangat persatuan, toleransi, kesatuan, pluralisme, dan kemanusiaan." (Pidato kenegaranaan presiden RI ke-6 pada sidang paripurna DPR-RI tanggal 15 Agustus 2014).

Tidak dapat dipungkiri bahwa pembukaan UUD 1945 juga harus dipertahankan karena di dalamnya terkandung cita-cita, tujuan nasional, dan dasar negara. selain itu NKRI juga sudah final dan tidak dapat di ganggu gugat. Keutuhan dan kedaulatannya tidak dapat dikompromikan. Penegakannya dapat dilakukaan dengan berbagai cara yang mengedepankan pendekatan keadilan dan kesejahteraan. Di tengah-tengah keadilan keragaman bangsa kita yang majemuk, selanjutnya slogan Bhineka Tunggal Ika harus selalu di aktualisasikan sebagai keniscayaan kehidupan bermasyarakat, berbangsa, dan bernegara yang terdiri dari beragam suku,agama,bahasa,dan budaya.

Bangsa Indonesia, dalam perjalanan sejarahnya mengalami kesengsaraan dan penderitaan yangg disebabkan oleh penjajahan. Oleh sebab itu Pembukaan Undang-Undang Dasar 1945, mengamatkan bahwa kemerdekaan adalah hak segala bangsa dan penjajahan diatas dunia harus dihapuskan karena tidak sesuai dengan perikemanusiaan dan 
perikeadilan. Bangsa Indonesia bertekad mengikuti ketertiban dunia berdasarkan kemerdekaan, perdamaian abadi dan keadilan sosial yang pada hakikatnya merupakan kewajiban setiap bangsa, sehingga bangsa Indonesia berpandangan bahwa hak asasi manusia tidak terpisahkan dengan kewajibannya. Berdasarkan hal tersebut diatas, maka bangsa Indonesia mempunyai pandangan dan sikap mengenai hak asasi manusia yang bersumber dari ajaran agama, nilai moral universal, dan nilai luhur budaya bangsa, serta berdasarkan pada Pancasila dan Undang - Undang Dasar 1945.

Bangsa Indonesia sebagai anggota Perserikatan Bangsa -Bangsa mempunyai tanggung jawab untuk menghormati Deklarasi Universal Hak Asasi Manusia (Universal Declaration of Human Rights) dan berbagai instrumen internasional lainnya mengenai hak asasi manusia.

Adapun Perumusan substansi hak asasi manusia menggunakan pendekatan normatif, empirik, deskriptif, dan analitik sebagai berikut:

a. Hak asasi manusia adalah hak dasar yang melekat pada diri manusia yang sifatnya kodrati dan universal sebagai karunia Tuhan Yang Maha Esa dan berfungsi untuk menjamin kelangsungan hidup, kemerdekaan perkembangan manusia dan masyarakat yang tidak boleh diabaikan, dirampas, ataudiganggu-gugat oleh siapapun.

b. Masyarakat Indonesia yang berkembang sejak masih sangat sederhana hingga modern, pada dasarnya merupakan masyarakat kekeluargaan. Masyarakat kekeluargaan telah mengenal pranata sosial yang menyangkut hak dan kewajiban warga masyarakat yang terdiri atas pranata religius yang mengakui bahwa manusia adalah ciptaan Tuhan Yang Maha Esa dengan segala hak an kewajibannya; pranata keluarga sebagai wadah manusia hidup bersama untuk mengembangkan keturunan dalam menjaga kelangsungan keberadaannya; pranata ekonomi yang merupakjan upaya manusia untuk meningkatkan kesejahteeraan; pranata pendidikan dan pengajaran untuk mengembangkan kecerdasan dan kepribadian manusia; pranata informasi dan komunikasi 8ntuk memperluas wawasan keterbukaan; pranata hukum dan keadilan untuk menjamin ketertiban dan kerukunan hidup; pranata keamanan untuk menjamin keselamatan setiap manusia. Dengan demikian substansi hak asasi manusia meliputi : hak untuk hidup ; hak berkeluarga dan melanjutkan keturunan; hak mengembangkan diri; hak keadilan; hak kemerdekaan; hak berkomunikasi; hak keamanan ; dan hak kesejahteaan.

c. Bangsa Indonesia menyadari dan mengakui bahwa setiap individu adalah bagian dari masyarakat dan sebaliknya masyarakat terdiri dari individu-individu yang mempunyai hak asasi serta hidup di dalam lingkungan yang merupakan sember daya bagi 
kehidupannya. Oleh karena itu tiap individu di samping mempunyai hak asasi juga mengembangkan kewajiban dan tanggung jawab untuk menghormati hak asasi individu lain, tata tertib masyarakat setia kelestarian fungsi, perbaikan tatanan dan peningkatan mutu lingkungan hidup.

Dimana Hak asasi merupakan hak dasar seluruh umat manusia tanpa ada perbedaan, Mengingat hak dasar adalah anugerah dari Tuhan Yang Maha Esa, maka pengertian hak asasi manusia adalah hak sebagai anugerah Tuhan Yang Maha Esa yang melekat pada diri manusia, bersifat kodrati, universal, dan abadi, berkaitan dengan harkat dan martabat manusia.Oleh karena itu setiap manusia diakui dan dihormati mempunyai hak asasi yang sama tanpa membedakan jenis kelamin, warna kulit, kebangsaan, agama, usia, pandangan politik, status sosial, dan bahasa serta status lain. Pengabaian atau perampasannya, mengakibatkan hilangnya harkat dan martabat sebagai manusia, sehingga kurang dapat mengembangkan diri dan peranannya secara utuh.Serta bangsa Indonesia menyadari bahwa hak asasi manusia bersifat historis dan dinamis yang pelaksanaannya berkembang dalam kehidupan bermasyarakat, berbangsa, dan bernegara.

Berdasarkan penjelasan tersebut bahwa Hak asasi Manusia Indonesia lahir sesuai dengan adat dan budaya serta tradisi yang terkandung dalam setiap kehidupan suku bangsa yang ada di Indonesia. Pancasila sebagai Dasar Negara telah mampersatukan hal tersebut dari segenap suku bangsa, karena masing-masing Sila mengandung atau memuat Hak-Hak Asasi Manusia Indonesia. Sebagai berikut :

1. Hak Asasi Manusia sesuai Sila Ketuhanan Yang Maha Esa : Sila Ketuhanan Yang Maha Esa mengandung pengakuan terhadap Tuhan Yang Maha Esa dan menjamin setiap orang untuk melakukan Ibadah menurut keyakinannya. Dengan Sila ini dijamin Kemerdekaan beragama bagi setiap orang, setiap Agama, kebebasan berbicara dari ketakutan yang dipandang sama hak dan kedudukannya terhadap Negara, berlaku adil antar sesama warganegara menghormati dan jangan merampas Hak orang lain, penuh kasih sayang, rasa keadilan dan kehidupan yang tentram. Bahwa adapun Kemerdekaan beragama ini telah mendapat pengakuan dalam Amandemen ke-1 dari Konstitusi Amerika Serikat. Pasal 10 Declaration Des Droits De L'homme Et Du Citoyen, adalah pengakuan Konstitusi Prancis yang terdapat pada Mukadimah alenia 19. Untuk Indonesia hak-hak asasi terdapat pada pasal 29 ayat 2 UUD 1945, ditindak lanjuti pada pasal 18 UUDS 1950 dan juga tercantum pada pasal 2 Rancangan MPRS tentang Piagam Hak-Hak Asasi Manusia dan Hak-Hak serta Kewajiban Warga Negara. Pada, Deklarasi PBB terdapat di pasal 18 Universal Declaration of Human Rights. 
2. Hak Asasi Manusia sesuai Sila Kemanusian Yang Adil dan Beradab :

Kemanusiaan yang adil dan Beradab, adalah sikap yang menghendaki terlaksananya human value dalam arti pengakuan dignity of man dan human freedom, setiap orang wajib dilakukan secara pantas, tidak boleh disiksa dan dihukum secara ganas, di hina atau diperlakukan secara melampaui batas.

Kemanusiaan mengakui seluruh manusia sama-sama makhluk Tuhan, dengan demikian segala bangsa sama tinggi dan sama rendahnya, ini berarti suatu pengakuan kemerdekaan bagi segala bangsa dengan menolak kolonialisme dan imperialisme.

Kemanusiaan juga berarti pengakuan manusia sebagai individu dan sebagai makhluk sosial, sebagai individu dia mempunyai hak-hak asasi yang dapat dipertahankannya dari ganggguan yang datang, baik dari pihak penguasa maupun dari individu lainnya.

Oleh karena Perikemanusiaan itu meliputi segala hal ikhwal mengenai Manusia dan perasaan terhadap sesama Manusia., oleh sebab itu Sila Kemanusiaan yang adil dan beradab sangat terkait erat dan sangkutpautnya dengan hak-hak dasar dan kebebasan asasi manusia. Hak-hak asasi yang telah mendapat pengakuan.Perwujudan dari Sila kemanusian adalah, Hak untuk tidak diperbudak, hak untuk tidak dianiaya, hak untuk tidak ditanggap, ditahan, dibuang secara sewenang-wenang, hak dianggap tidak bersalah sampai dibuktikan kesalahannya menurut hukum atau undang undang dan sebagainya.

3. Hak Asasi Manusia pada Sila Persatuan Indonesia :

Persatuan Indonesia atau Kebangsaan, ialah sikap yang mengutamakan kepentingan bangsa diatas Suku Bangsa, Golongan, Partai dan lain-lain ini berati persatuan antara golongangolongan , suku - suku dan partai - partai yang mempunyai kedudukan dan kesempatan yang sama dalam Negara Republik Indonesia yang memiliki arti keseimbangan yang harmonis dengan tidak mengutamakan yang satu dengam mengabaikan yang lainnya. Kesadaran Kebangsaan Indonesia, lahir dari keinginan untuk bersatu, agar setiap orang Indonesia dapat bebas menikmati hak-hak asasinya dan pembatasan dan belenggu dari manapun datangnya. Kesadaran kebvangsaan adalah titik tolak dalam perjuangan mempertahankan hak asasi manusia, sebab tanpa adanya kesadaran kebangsaan ini tidak ada suatu jaminan bahwa hak asasi itu mendapat perlindungan. Bahwa untuk tidak menjadi penyebab terlnbggarnya hak asasi dari bangsa-bangsa lain, maka perasaan kebangsaan itu ke luar harus bersifat Persahatbatan yang bersifat Universal dengan bangsa- 
bangsa lain dalam suatu Persamann Derajat dan HormatMenghormati, anti Imperalisme dan kolonialisme atau dengan perkataan lain tidak Eksklusif dan tidak Chauvinis.

4. Hak Asasi manusia sesuai Sila Kerakyattan yang dipimpin oleh hikmat Kebijaksannann dalam Permusyawaratan / Perwakilan (Kedaulatan Rakyat ) :

Negara terbentuk dari Rakyat oleh Rakyat dan untuk Rakyat dan Kedaulatan Rakyat berarti Kekuasann dalam Negara. Kedaulatan Rakyat adalah penjelmaan dari Demokrasi Indonesia yang dikenal dengan Demokrasi Pancasila. Kedaulatan Rakyat berisi pengakuan akan harkat dan martabat manusia, wujud Pengakaan Rakyat adalah menghormati dan menjujungi Tinggi segala hak-hak asasi yang melekat padanya. Wujud nyata dari Kedaulatan Rakyat dalam Hak asasi Manusia Indonesia adalah Hak mengeluarkan pendapat, Hak berkumpul dan berapat, Hak ikut serta dalam Pemerintahan dan Jabatanjabatan Negara, Keemerdekaan Pers dan lain-lain, yang sudah tentu sesuai dengan jiwa Pancasila. Hak Asasi manusia dalam Kedaulatan Rakyat bersifat Musyawarah dan mufakat serta tenggang rasa berdasarkan Kerakyatan yang dipimpin oleh hikmah kebijaksanaan dalam Permusyawaratan / Perwakilan.

5. Hak Asasi Manusia sesuai Sila Keadilan Sosial bagi seluruh rakyat Indonesia :
Hak asasi manusia dalam keadilan sosial terwujud melaksanakan Kesejahteraan Umum dan Keadilan yang dimaksud ialah keadilan yang memberi pertimbangan dimana hak milik berfungsi sosial. Keadilan sosial berarti tiap-tiap orang dapat menikmati kehidupan yang layak sebagai manusia yang terhormat, dalam arti tidak ada kepincangan antar golongan yang hidup Mewah dengan golongan lain yang melarat atau dengan kata lain tiap orang harus mendapat kesempatan yang sama untuk mendapat nafkah dan jaminan hidup yang layak dalam lapangan ekonomi dan sosial tanpa saling merugikan, menindas, melainkan saling harga-menghargai, bantumembantu sesama Manusia dan Negara. Hak asasi manusai dalam paham Keadilan Sosial adalah dijaminnya hak untuk hidup layak, dijamin adanya hak milik, adanya hak atas jaminan sosial, adanya hak atas pekerjaan dengan sistim pengupahan dari syarat-syarat kerja yang adil dan baik, berhak atas tingkat hidup yang menjamin kesehatan dan lainnya, yang kesemuannya itu telah menjadi Hak Asasi Manusia yang telah diakui UUD 1945 / Pancasila maupun Universal Declaration of Human Rights.

\section{PENUTUP}

Pancasila sebagai filsafat bangsa dan ideologi negara dihubungkan dengan fungsinya sebagai dasar negara, yang merupakan landasan idiil bangsa Indonesia dan negara Republik Indonesia dapat disebut pula sebagai Ideologi Nasional atau lebih tepat lagi ideologi negara. Artinya Pancasila 
merupakan satu ideologi yang dianut oleh negara atau pemerintah dan rakyat Indonesia secara keseluruhan, bukan milik atau dapat dimonopoli oleh seseorang, ataupun sesuatu golongan masyarakat tertentu. Sebagai dasar filsafat atau dasar kerohanian negara, yang merupakan cita-cita bangsa, Pancasila harus dilaksanakan atau diamalkan. Bangsa Indonesia, dalam perjalanan sejarahnya mengalami kesengsaraan dan penderitaan yangg disebabkan oleh penjajahan. Oleh sebab itu Pembukaan Undang-Undang Dasar 1945, mengamatkan bahwa kemerdekaan adalah hak segala bangsa dan penjajahan diatas dunia harus dihapuskan karena tidak sesuai dengan perikemanusiaan dan perikeadilan. Bangsa Indonesia bertekad mengikuti ketertiban dunia berdasarkan kemerdekaan, perdamaian abadi dan keadilan sosial yang pada hakikatnya merupakan kewajiban setiap bangsa, sehingga bangsa Indonesia berpandangan bahwa hak asasi manusia tidak terpisahkan dengan kewajibannya.

\section{DAFTAR PUSTAKA}

Himpunan Peraturan Perundangundangan yang terkait dengan HAM, MA RI 2000

Jimly Asshiddiqie , Edisi revisi 2006, Konstitusi dan Konstitusionalisme Indonesia, Konstitusi Perss.

Kaelan ,2002, Pendidikan Pancasila Edisi Reformasi, Paradigma Yogyakarta

Kansil, Christine S.T Kansil, 2005, Pancasila dan UUD 1945, Pradnya Paramita.
Subandi AL Marsudi , Edisi Revisi 2006, Pancasila dan UUD 1945 Dalam Paradigma Reformasi, PT. Raja Grafindo Persada, Jakarta

Suryatni. L. 2014. Diktat pendidikan pancasila dan kewarganegaraan

Susilo Bambang Yudhoyono, Presiden RI ke-6 ,Pidato Kenegaraan 15 Agustus 2014 di Gedung MPR-DPR RI, Jakarta. 